\title{
REVIEW
}

\section{Bench-to-bedside review: Hypothermia in traumatic brain injury}

\author{
H Louise Sinclair and Peter JD Andrews*
}

\begin{abstract}
Traumatic brain injury remains a major cause of death and severe disability throughout the world. Traumatic brain injury leads to 1,000,000 hospital admissions per annum throughout the European Union. It causes the majority of the 50,000 deaths from road traffic accidents and leaves 10,000 patients severely handicapped: three quarters of these victims are young people. Therapeutic hypothermia has been shown to improve outcome after cardiac arrest, and consequently the European Resuscitation Council and American Heart Association guidelines recommend the use of hypothermia in these patients. Hypothermia is also thought to improve neurological outcome after neonatal birth asphyxia. Cardiac arrest and neonatal asphyxia patient populations present to health care services rapidly and without posing a diagnostic dilemma; therefore, therapeutic systemic hypothermia may be implemented relatively quickly. As a result, hypothermia in these two populations is similar to the laboratory models wherein systemic therapeutic hypothermia is commenced very soon after the injury and has shown so much promise. The need for resuscitation and computerised tomography imaging to confirm the diagnosis in patients with traumatic brain injury is a factor that delays intervention with temperature reduction strategies. Treatments in traumatic brain injury have traditionally focussed on restoring and maintaining adequate brain perfusion, surgically evacuating large haematomas where necessary, and preventing or promptly treating oedema. Brain swelling can be monitored by measuring intracranial pressure (ICP), and in most centres ICP is used to guide treatments and to monitor their success. There is an absence of evidence for the five commonly used treatments for raised ICP and all are potential 'double-edged swords' with significant disadvantages. The use of hypothermia in patients with traumatic brain injury may have beneficial effects in both ICP reduction and possible neuro-protection. This review will focus on the bench-to-bedside evidence that has supported the development of the Eurotherm3235Trial protocol.
\end{abstract}

\section{Introduction}

It is important to remember that traumatic brain injury (TBI) is a major cause of death and severe disability throughout the world. TBI leads to 1,000,000 hospital admissions per annum throughout the European Union. It causes the majority of the 50,000 deaths from road traffic accidents and leaves 10,000 patients severely handicapped: three quarters of these victims are young people [1]. Additionally, TBI causes 290,000 hospital admissions and 51,000 deaths and leaves 80,000 patients with permanent neurological disabilities in the US annually [2]. The consequence of this is both a devastating emotional and physical impact and an enormous financial burden [3].

*Correspondence: p.andrews@ed.ac.uk

Department of Anaesthesia, Critical Care and Pain Medicine, University of Edinburgh, Western General Hospital, Crewe Road, Edinburgh, EH4 2XU, UK
Therapeutic hypothermia has been shown to improve outcome after cardiac arrest [3], and consequently the European Resuscitation Council and American Heart Association guidelines $[4,5]$ recommend the use of hypothermia in these patients. Hypothermia is also thought to improve neurological outcome after neonatal birth asphyxia [6]. Cardiac arrest and neonatal asphyxia patient populations present to health care services rapidly and without posing a diagnostic dilemma; therefore, therapeutic systemic hypothermia may be implemented relatively quickly. As a result, hypothermia in these two populations is similar to the laboratory models wherein systemic therapeutic hypothermia is commenced very soon after the injury and has shown so much promise [7].

The need for resuscitation and computerised tomography (CT) imaging to confirm the diagnosis in patients with TBI is a factor that delays intervention with temperature reduction strategies. Treatments in TBI have traditionally focussed on restoring and maintaining adequate brain perfusion, surgically evacuating large 
Table 1. Possible mechanisms underlying the beneficial effects of hypothermia

\begin{tabular}{|c|c|c|}
\hline Secondary injury & Explanation & Time frame after injury \\
\hline Prevention of apoptosisa & $\begin{array}{l}\text { Ischaemia can induce apoptosis and calpain-mediated proteolysis. This process can be } \\
\text { prevented or reduced by hypothermia. }\end{array}$ & $\begin{array}{l}\text { Hours to days to } \\
\text { even weeks }\end{array}$ \\
\hline $\begin{array}{l}\text { Reduced mitochondrial } \\
\text { dysfunction and improved } \\
\text { energy homeostasis }\end{array}$ & $\begin{array}{l}\text { Mitochondrial dysfunction is a frequent occurrence in the hours to days after a period of } \\
\text { ischaemia and may be linked to apoptosis. Hypothermia reduces metabolic demands and } \\
\text { may improve mitochondrial function. }\end{array}$ & Hours to days \\
\hline $\begin{array}{l}\text { Reduction in free radical } \\
\text { production }^{\mathrm{b}}\end{array}$ & $\begin{array}{l}\text { Production of free radicals (for example, superoxide, peroxynitrate, hydrogen peroxide, and } \\
\text { hydroxyl radicals) is typical in ischaemia. Mild-moderate }\left(30^{\circ} \mathrm{C} \text { to } 35^{\circ} \mathrm{C}\right) \text { hypothermia is able to } \\
\text { reduce this event. }\end{array}$ & Hours to days \\
\hline $\begin{array}{l}\text { Mitigation of reperfusion } \\
\text { injury }^{b}\end{array}$ & $\begin{array}{l}\text { Cascade of reactions following reperfusion, partly mediated by free radicals but with } \\
\text { distinctive and various features. These are suppressed by hypothermia. }\end{array}$ & Hours to days \\
\hline $\begin{array}{l}\text { Reduced permeability of } \\
\text { the blood-brain barrier and } \\
\text { the vascular wall and } \\
\text { reduced oedema formation }\end{array}$ & $\begin{array}{l}\text { Blood-brain barrier disruptions induced by trauma or ischaemia are moderated by } \\
\text { hypothermia. The same effect occurs with vascular permeability and capillary leakage. }\end{array}$ & Hours to days \\
\hline $\begin{array}{l}\text { Reduced permeability of } \\
\text { cellular membranes } \\
\text { (including membranes of } \\
\text { the cell nucleus) }\end{array}$ & $\begin{array}{l}\text { Decreased leakage of cellular membranes with associated improvements in cell function } \\
\text { and cellular homeostasis, including decrease of intracellular acidosis and mitigation of } \\
\text { DNA injury }\end{array}$ & Hours to days \\
\hline Improved ion homeostasis & $\begin{array}{l}\text { Ischaemia induces accumulation of excitatory neurotransmitters such as glutamate and } \\
\text { prolonged excessive influx of } \mathrm{Ca}^{2+} \text { into the cell. This activates numerous enzyme systems } \\
\text { (kinases) and induces a state of hyperexcitability (exitotoxic cascade) that can be moderated } \\
\text { by hypothermia. }\end{array}$ & First minutes to 72 hours \\
\hline Reduced metabolisma & $\begin{array}{l}\text { Cellular oxygen and glucose requirements are reduced by } 5 \% \text { to } 8 \% \text { per degree Celsius } \\
\text { decrease in temperature. }\end{array}$ & Hours to days \\
\hline $\begin{array}{l}\text { Depression of the immune } \\
\text { response and various } \\
\text { potentially harmful } \\
\text { pro-inflammatory reactions }{ }^{\mathrm{a}}\end{array}$ & $\begin{array}{l}\text { Sustained destructive inflammatory reactions and secretion of pro-inflammatory cytokines } \\
\text { after ischaemia can be blocked or mitigated by hypothermia. }\end{array}$ & First hour to 5 days \\
\hline $\begin{array}{l}\text { Reduction in cerebral } \\
\text { thermopooling }\end{array}$ & $\begin{array}{l}\text { Some areas in the brain have significantly higher temperatures than others. These differences } \\
\text { can increase dramatically after injury with temperatures that are up to } 2^{\circ} \mathrm{C} \text { to } 3^{\circ} \mathrm{C} \text { higher in } \\
\text { injured areas. Hyperthermia can increase the damage to the injured brain cells; this is } \\
\text { mitigated by hypothermia. }\end{array}$ & Minutes to days \\
\hline Anticoagulant effects ${ }^{a}$ & $\begin{array}{l}\text { Microthrombus formation may add to brain injury after CPR. Anticoagulant effects of } \\
\text { hypothermia may prevent thrombus formation. }\end{array}$ & Minutes to days \\
\hline $\begin{array}{l}\text { Suppression of epileptic } \\
\text { activity and seizures }\end{array}$ & $\begin{array}{l}\text { Seizures after ischaemic injury or trauma are common and may add to injury. Hypothermia } \\
\text { has been shown to mitigate epileptic activity. }\end{array}$ & Hours to days \\
\hline
\end{tabular}

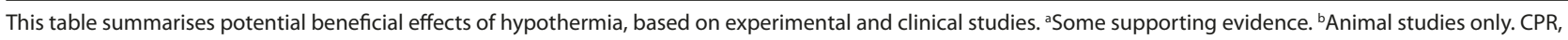
cardiopulmonary resuscitation.

haematomas where necessary, and preventing or promptly treating oedema [3]. Brain swelling can be monitored by measuring intracranial pressure (ICP), and in most centres ICP is used to guide treatments and to monitor their success. There is an absence of evidence for the five commonly used treatments for raised ICP and all are potential 'double-edged swords' with significant disadvantages. The use of hypothermia in patients with TBI may have beneficial effects in both ICP reduction and possible neuro-protection.

\section{Pathophysiology}

Ischaemia has a key role in all forms of brain injury and preventing ischaemic (or secondary) injury is at the core of all neuro-protective strategies [3]. A complex cascade of processes ensues at the cellular level after a period of ischaemia (Table 1), beginning from minutes to hours after injury and continuing for up to 72 hours or longer. Thus, there may be a window of opportunity of several hours, or even days, during which injury can be mitigated by treatments such as hypothermia [3].

Early studies that used profound hypothermia in models of brain trauma gave inconsistent results. More recent studies have shown that moderate/mild hypothermia appears to be neuro-protective in well-characterised rodent models of TBI. The effects of systemic hypothermia $\left(30^{\circ} \mathrm{C}\right.$ to $\left.36^{\circ} \mathrm{C}\right)$ following fluid percussion brain injury in rats were first investigated by Clifton and colleagues [8], who showed that hypothermia of $33^{\circ} \mathrm{C}$ reduced mortality rates and attenuated deficits in motor function and weight loss compared with normothermia. Dietrich and colleagues [9] showed that post-traumatic hypothermia $\left(30^{\circ} \mathrm{C}\right)$ initiated 5 minutes after fluid percussion brain injury reduced overall contusion volume 
and preserved survival of the overlying cortical neurons. Therefore, these studies demonstrated that cooling after a TBI provided histological/cellular protection, improved motor and cognitive function, and reduced mortality. Moderate hypothermia $\left(30^{\circ} \mathrm{C}\right)$ initiated 5 minutes after TBI improved hippocampal-dependent learning and memory using the Morris water maze [10]. An important predictor of outcome in TBI patients, traumatic axonal pathology, is reduced with moderate post-injury hypothermia therapy [11]. Therefore, post-traumatic hypothermia modulates the major pathologies in TBI such as contusions, neuronal vulnerability, and traumatic axonal injury. Mild hypothermia is therefore potentially attractive as it modulates multiple mechanisms or pathways and has advantages over unipolar pharmacological attempts to provide neurological protection.

\section{Blood-brain barrier}

Alterations in blood-brain barrier (BBB) permeability after acute injury result in the crossing of water, electrolytes, blood-borne substances, and potential neurotoxic agents across the vascular system and into the brain parenchyma. Many studies have demonstrated the importance of brain and body temperature on the microvascular consequences of cerebral ischaemia and trauma. One study that assessed the effects of intra-ischaemic brain temperature (mild hypothermia) on $\mathrm{BBB}$ was shown to reduce extravasation of the protein tracer horseradish peroxidase [12]. Brain water content is significantly reduced with hypothermia after focal cerebral ischaemia $[13,14]$. Recent studies have assessed this with magnetic resonance imaging and found that reductions in the apparent diffusion coefficient of water (cellular oedema) are also attenuated by hypothermia [15].

In models of post-traumatic injury, hypothermia has also been shown to reduce BBB permeability. Hypothermia may be attenuating $\mathrm{BBB}$ permeability by altering matrix metalloproteinases, which are critical extracellular enzymes that can disrupt the BBB [16]. These modulating effects of hypothermia on BBB permeability are important beneficial mechanisms because of the association between BBB permeability, formation of vasogenic oedema, the extravasation of circulating inflammatory cells and adverse post-injury outcomes.

\section{Inflammation and oedema}

The inflammatory response after TBI is significantly modulated by hypothermia in laboratory and clinical studies. As well as attenuating the increase in BBB permeability and leucocyte margination, the endogenous inflammatory response of the central nervous system (CNS) is reduced by hypothermia. Astrocytes and microglia respond to CNS injury by proliferating around the injury areas and releasing pro-inflammatory communication molecules as an endogenous repair mechanism. Hypothermia significantly attenuates the activation of both astrocytes and microglia [17-20]. Combination therapy including the anti-inflammatory cytokine interleukin-10 and hypothermia therapy was attempted in both TBI and focal cerebral ischaemia [21]. Synergistic effects were seen in focal cerebral ischaemia but not in TBI, suggesting that the cellular biology of inflammation in these two major CNS injuries has an influence on the effect of subsequent hypothermia. Another major aspect of the inflammatory response to CNS injury is the release of reactive oxygen species by astrocytes and microglia. Hypothermia reduces increases in tissue levels of superoxide, nitric oxide, and the hydroxyl radical [22,23]. Superoxide dismutase, the enzyme responsible for scavenging superoxide, is increased by hypothermia [24,25], and the enzyme responsible for synthesising nitric oxide, nitric oxide synthase, is attenuated by hypothermia [26].

\section{Metabolism}

Exploiting local measures of glucose metabolism using 2-deoxyglucose techniques, researchers showed that moderate hypothermia $\left(30^{\circ} \mathrm{C}\right)$ reduced glucose utilisation compared with normothermia [27]. Metabolic effects of mild hypothermia have also been shown using nuclear magnetic resonance spectroscopy, in which the metabolic effects of different levels of hypothermia were reported [28]. Therefore, hypothermia lowers metabolic and energy demands, having potentially beneficial effects on cytoplasmic ATP and the maintenance of normal transmembrane ion and neurotransmitter gradients. The magnitude of preservation of ATP levels depends on both the temperature reduction and the severity of the injury. Therefore, an important mechanism for the neuroprotective effects of hypothermia is a reduction or delay in metabolic demand during and after an acute CNS injury.

\section{Excitotoxicity}

The effects of moderate hypothermia on glutamate excitotoxicity were reported using microdialysis to assay extracellular/extravascular concentrations of neurotransmitters after global ischaemia. The middle cerebral artery occlusion model is considered a reasonable model for traumatic hemorrhagic contusion (John Povlishock, personal communication). Busto and colleagues [22] showed that intra-ischaemic hypothermia $\left(33^{\circ} \mathrm{C}\right.$ and $30^{\circ} \mathrm{C}$ ) attenuated the rise in extracellular levels of glutamate and dopamine after global cerebral ischaemia. These studies have been replicated in a variety of models of ischaemia, indicating that one of the major mechanisms by which temperature affects neuronal vulnerability is through reducing excitotoxicity following cerebral ischaemia [22,29,30]. Delayed pharmacological 
treatments that reduce excitotoxicity further improve outcome in combination with hypothermia [31] and may be a promising strategy for further studies. The glutamatergic receptors, AMPA (alpha-amino-3-hydroxyl-5methyl-4-isoxazole-propionate) and NMDA ( $N$-methyl D-aspartate), are also modulated by hypothermia. Expression of hippocampal glutamate receptors is decreased after transient global ischaemia and this is completely blocked by intra-ischaemic hypothermia [32]

Other neurotransmitters are also modulated by hypothermia. Lyeth and colleagues [33] demonstrated that hypothermia $\left(30^{\circ} \mathrm{C}\right)$ reduced elevations in cerebrospinal levels of acetylcholine after TBI. Conversely, hypothermia delayed decreases in dopamine, norepinephrine, and serotonin after global cerebral ischaemia [34]. But other studies have demonstrated that hypothermia $\left(32^{\circ} \mathrm{C}\right)$ can improve outcome after CNS injury without attenuating extracellular levels of glutamate and aspartate $[11,28,35]$. The neurotransmitter response, in various injury models, may be temperature-dependent, but attenuating other injury cascades may be more important in delivering possible beneficial effects of hypothermia.

\section{Cerebrovascular effects}

The effects of hypothermia on cerebral blood flow are controversial. In 1954, Rosomoff and Holaday [36] demonstrated that systemic hypothermia to $25^{\circ} \mathrm{C}$ significantly lowered cerebral blood flow. However, in a model of selective brain cooling $\left(30^{\circ} \mathrm{C}\right)$, cortical blood flow measured by laser Doppler flowmetry was shown to increase above control levels [37]. Cerebrovascular changes secondary to cooling the brain are important because reductions in blood flow to critical levels could have adverse effects on tissue survival and functional outcome.

\section{Intracellular calcium-dependent signalling}

There are pronounced changes in calcium-dependent intracellular signalling pathways after CNS injury. Normal neuronal activity is mediated by signalling through protein kinases and several of these have been documented to be disrupted by TBI and cerebral ischaemia. Temporary cerebral ischaemia inhibits the activity of calcium/calmodulin-dependent protein kinase II (CaMKII), a key protein kinase that mediates synaptic strength and this is attenuated by hypothermia [38]. Protein kinase $\mathrm{C}(\mathrm{PKC})$ translocates to the membrane after cerebral ischaemia and undergoes inhibition; hypothermia rescues the inhibition of PKC activity and its translocation to the membrane [39]. Recently, various transcription factors that participate in normal neuronal functioning have been shown to be sensitive to temperature. The immediate early gene $c$-Fos, which regulates key genetic responses of neurons, is activated by hypothermia after transient global ischaemia [17,40,41]. These studies underline that temperature may have profound effects on events associated with neuronal injury as well as the normal processing of neuronal signals throughout brain circuits.

\section{Neuronal cell death}

Although neuronal necrosis is commonly seen in most CNS injury models, evidence for apoptotic cell death has also been documented using various histochemical and molecular techniques. As with necrosis, apoptotic cell death appears to be sensitive to post-injury hypothermic treatment strategies. Recent studies indicate that apoptotic cell death is another important target by which temperature may affect long-term outcome in various models of CNS injury. Various gene families (genes with a similar sequence of DNA nucleotides) have been shown to be sensitive to post-injury temperature manipulations in models of ischaemia and trauma [42]. The ability of post-injury temperature to affect the acute and more delayed genetic response to injury is important in that these genes may be important in determining the cellular response or responses that result in secondary injury. Genomic studies using high-throughput screening and bioinformatics are ongoing in many laboratories and these contemporary technologies will help to determine how hypothermia may protect and potentially repair CNS tissues after injury.

Systematic review and meta-analysis have not been rigorously applied to TBI models. Such an approach is beyond the scope of this paper but in the future would enhance translational research and (hopefully) reduce futile studies. The CAMARADES (Collaborative Approach to Meta Analysis and Review of Animal Data from Experimental Stroke) group have successfully applied such methodology to stroke models [43].

Therefore (with the proviso above), numerous animal experiments, in different species, have shown that induced hypothermia improves outcome after experimental TBI. This has led to the undertaking of a large number of clinical trials [3]. Interpretation of these results is complicated by the fact that these studies have enrolled different categories of patients, with different types of injuries, and have used widely diverging treatment protocols [44]. Most have used elevated ICP as an inclusion criterion although some have used a CT scan criterion. The duration of cooling has varied from 24 hours to more than 5 days, and re-warming rates have also varied. Some studies have used ICP to guide depth and duration of treatment, although responses to rebound intracranial hypertension have differed [3]. Cointerventions such as osmotic therapy, sedation, analgesia, paralysis, and targets for mean arterial pressure and cerebral perfusion pressure have also varied 
considerably [3]. All of these factors can affect outcome after TBI in general and the potential efficacy of cooling in particular. Thus, interpreting, comparing, and aggregating the results of these studies present a number of complex challenges.

\section{Review of clinical evidence}

There have been eight meta-analyses carried out on this subject from the years 2002 to 2009. This section is a literature review of the available evidence. In total, 29 clinical studies have been performed to assess the effects of hypothermia in TBI. Twenty-seven of these were performed in adult patients, and 18 of these 27 included control groups. Data from one pilot study were subsequently included in a larger study, therefore leaving 17 studies. As outlined above, study protocols have differed considerably, and not all studies were (properly) randomised [3]. A total of 131 patients were enrolled into two studies undertaken in patients with normal ICP. Only one of these studies reported outcome data (at 3 months) and the results showed no significant difference between groups (good outcome in 21/45 [hypothermia] versus 27/46 patients [controls], $P=0.251$ ) [45].

Eighteen studies, with outcome data available for 2,096 patients, used hypothermia in patients with high ICP that was refractory to 'conventional' treatments (usually sedation/analgesia, paralysis, osmotic therapy, and sometimes barbiturates) [46-61]. All observed decreases in ICP during cooling. Thirteen of these studies reported significant improvements in outcome associated with hypothermia [45,49-51,53,54,56-60,62,63]. All of these were performed in specialised neurotrauma centres with experience in applying hypothermia and managing its side effects. Ten were single-centre studies $[47,49,51,53,5$ $4,57,59,60,62,63]$, and three (all performed in China) $[51,62,63]$ were multi-centre. Four additional studies $[48,52,55,58]$ observed a trend to improved outcome, but these differences were not statistically significant.

In contrast, one of the two largest multi-centre randomised controlled trials (RCTs) failed to show that induced hypothermia improved outcome at 6 months after TBI (relative risk [RR] of a poor outcome 1; $95 \%$ confidence interval [CI] 0.8 to $1.2 ; P=0.99$ ) [46]. Significantly more of the patients admitted to hospital with hypothermia who were randomly assigned to normothermia, and consequently re-warmed, had a poor outcome $(78 \%, \mathrm{n}=31)$ compared with patients admitted with hypothermia and treated with hypothermia $(61 \%$, $\mathrm{n}=38)(P=0.09)$.

On subsequent analysis, it became clear that although this study was methodologically well designed, there was marked inter-centre variance in the treatment effect of hypothermia, age of participants, severity of illness scoring between groups, management of intracranial hypertension, and haemodynamic and fluid management [64]. Induced hypothermia in the hypothermia group was started relatively late with a slow speed of cooling (average time to target temperature of more than 8 hours) in all centres.

Hypotension (lasting more than 2 hours) and hypovolaemia occurred three times more frequently in the hypothermia group. Bradycardia associated with hypotension occurred four times more frequently in this group, and electrolyte disorders and hyperglycaemia were also found more frequently in the hypothermia group [46]. All of these complications are known side effects of hypothermia. Most are easily preventable with good intensive care and should not be regarded as inevitable consequences of hypothermia treatment. Since even very brief episodes of hypotension or hypovolaemia can adversely affect outcome in TBI, these and other issues may have significantly affected the results of this trial [65-67]. One possible problem was that some of the participating centres had little or no previous experience in using hypothermia. Large centres familiar with cooling showed apparently favourable neurological outcomes whereas smaller centres showed poor outcomes.

\section{Induction of hypothermia}

The most widely accepted use of hypothermia is after cardiac arrest. Two RCTs in this patient group have shown significant neurological improvements in patients who were treated with hypothermia many hours after injury and whose initial cardiac rhythm was ventricular fibrillation or ventricular tachycardia [68,69]. Subsequent data from a large study of patients after myocardial infarction suggest that infarct size was reduced in patients who were cooled to less than $35^{\circ} \mathrm{C}$ before coronary intervention [70], thus suggesting that faster cooling rates may be beneficial to patient outcome.

Methods of cooling can be broadly divided into surface and core cooling techniques [71]. The above study used surface cooling devices alone and found that large numbers of patients did not reach the target temperature quickly enough before the start of the coronary intervention [70]. Despite advancing technology in surface cooling devices and the introduction of endovascular catheters for core cooling, average periods of 2 to 3 hours are still required to reach temperatures of $32^{\circ} \mathrm{C}$ to $34^{\circ} \mathrm{C}$ [71]. The currently available surface cooling devices are also relatively large and cumbersome. This coupled with the need for staff with specialist knowledge of the management of induced hypothermia may prevent its use outside of the intensive care unit [71].

A recent study examined the feasibility, speed, and complication rates of infusing refrigerated fluids intravenously to quickly induce hypothermia in patients with various neurological injuries [71]. Results showed that a 
$1,500 \mathrm{~mL}$ infusion of $0.9 \%$ saline, administered over the course of 30 minutes in patients without cardiogenic shock, reduced core temperature from $36.9^{\circ} \mathrm{C} \pm 1.9^{\circ} \mathrm{C}$ to $34.6^{\circ} \mathrm{C} \pm 1.5^{\circ} \mathrm{C}$ at 30 minutes and to $32.9^{\circ} \mathrm{C} \pm 0.9^{\circ} \mathrm{C}$ at 60 minutes. Continuous monitoring of arterial blood pressure, heart rhythm, central venous pressure, arterial blood gasses, and serum levels of electrolytes, platelets, and white blood cells showed no significant adverse events [71].

When hypothermia develops, the body will immediately try to counteract the temperature drop to maintain homeostasis [72]. One of the key mechanisms of heat production is shivering, which can lead to an increased oxygen consumption of $40 \%$ to $100 \%$, which may be detrimental in this patient population. Sedation drugs are known to increase peripheral blood flow and, in turn, increase the transfer of heat from the core to the peripheries, thus reducing core temperature [72]. Therefore, shivering may be counteracted by the administration of sedatives, anaesthetic agents, opiates, and/or paralysing agents [72].

It should be noted, however, that the capacity and effectiveness of the mechanisms of controlling body temperature decrease with age. Younger patients will therefore react earlier and with greater intensity than older patients. For this reason, induction of hypothermia in younger patients often requires high doses of sedation drugs to neutralise the counter-regulatory mechanisms [72].

\section{Meta-analyses}

Eight meta-analyses have been published between the years 2000 and 2009 [73-80]. These include various numbers of trials, with varying quality of randomisation and blinding procedures. All have found a trend to positive effects of hypothermia on neurological outcome, although statistical significance was reached in only two reviews: RR of improved neurological outcome of 0.78 (95\% CI 0.63 to 0.98 ) [73] and RR of 0.68 (95\% CI 0.52 to 0.89) [74]. Since submission of this manuscript, two Cochrane systematic reviews (issue 1 [79] and updated issue 2 [80] from 2009) have been published (Figure 1). The authors found that hypothermia may be effective in reducing death and unfavourable outcomes, but significant benefit was found only in low-quality trials. The high-quality trials found some non-significant benefit of hypothermia.

The meta-analysis of Peterson and colleagues [78] included eight trials that studied comparable patient groups at baseline. Hypothermia was shown to reduce mortality by $20 \%$, although this was not statistically significant (RR 0.80, 95\% CI 0.59 to 1.09). Subgroup analysis showed that this effect was significantly greatest when hypothermia was maintained for more than 48 hours
(RR $0.51,95 \%$ CI 0.33 to 0.79). Hypothermia was also associated with a non-significant increase of $25 \%$ in neurological outcome when measured by the Glasgow Outcome Scale at 6 months (RR 1.25, 95\% CI 0.96 to 1.62). Despite not reaching statistical significance, results showed an increased likelihood of improved neurological outcome when cooling was maintained for more than 48 hours (RR 1.91, 95\% CI 1.28 to 2.85). Another key finding of this meta-analysis is that hypothermia was of significant benefit only to those patients who had not received barbiturate therapy (RR $0.58,95 \%$ CI 0.40 to 0.85 ).

A criticism of these analyses is that most failed to take account of important differences in patient groups (such as those with or without intracranial hypertension) and of differences in treatment protocols, except the use of hypothermia. Only one differentiated between studies that enrolled patients with normal ICP and those that enrolled patients with intracranial hypertension and that analysis found no neurological improvement associated with hypothermia [77]. Only two assessed effects of treatment duration and speed of re-warming [73,74], concluding that cooling for more than 48 hours and rewarming rates of 24 hours, or $1^{\circ} \mathrm{C} / 4$ hours, were key factors in reducing mortality (RR $0.70,95 \%$ CI 0.56 to 0.87 ) and improving neurological outcome (RR 0.79, 95\% CI 0.63 to 0.98$)$, respectively.

In summary, the evidence from previous research shows that induced hypothermia may be effective in patients with severe TBI and intracranial hypertension provided that the treatment is continued for long enough (between 48 hours and 5 days) and that patients are rewarmed slowly $\left(1^{\circ} \mathrm{C} / 4\right.$ hours $)$. Experience with cooling also appears to be important if complications that may outweigh the benefits of hypothermia are to be avoided.

\section{Rationale for Eurotherm3235Trial}

The Eurotherm3235Trial will enrol TBI patients who have an ICP of more than $20 \mathrm{~mm} \mathrm{Hg}$ for at least 5 minutes after first-line treatments with no obvious reversible cause (for example, patient position, coughing, or inadequate sedation). Three stages of TBI management have been developed to support the trial and are based upon the best evidence available (Figure 2) [73,81]. The Brain Trauma Foundation's recommended treatment threshold for treatment of ICP is $20 \mathrm{~mm} \mathrm{Hg}$ [73]. Although early cooling after injury is considered to be beneficial, this is offset by the failure to show benefit from hypothermia in the absence of raised ICP. Enrolment to the Eurotherm3235Trial will therefore be allowed for up to 72 hours following injury. This potential delay in cooling will be compensated for, to an extent, by inducing hypothermia with 20 to $30 \mathrm{~mL} / \mathrm{kg}$ of refrigerated $0.9 \%$ saline given intravenously over the course of 30 minutes. No maximum duration of cooling is specified, and 


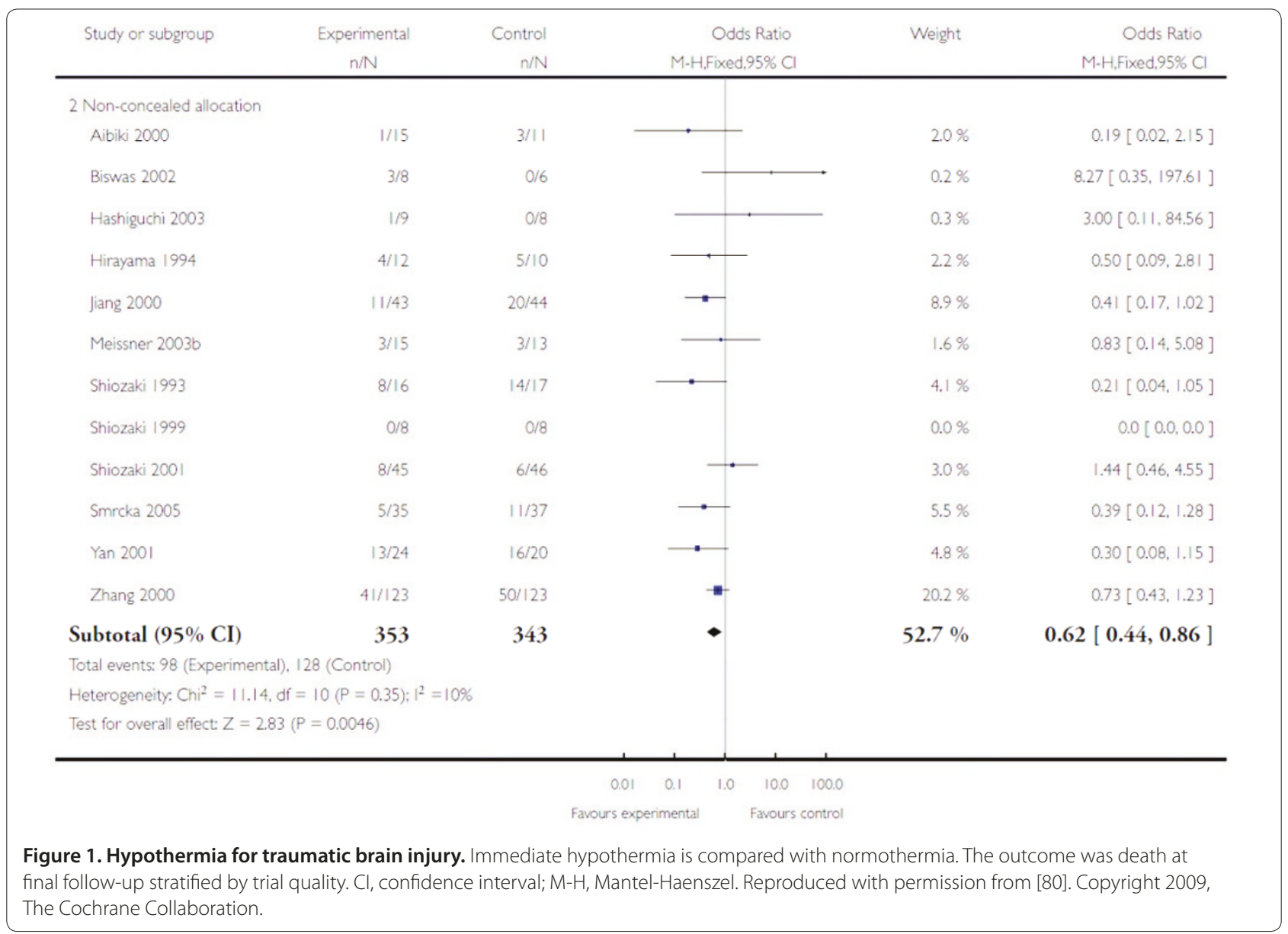

\begin{tabular}{|c|c|c|}
\hline $\begin{array}{c}\text { STAGE } 1 \\
\text { Admission to the Intensive } \\
\text { Care Unit (ICU) } \\
\text { Ventilation } \mathrm{PaO}_{2} \geq 11 \mathrm{kpa} \\
\mathrm{PaCO}_{2} 4.5-5.0 \mathrm{kpa} \\
\text { Sedation } \\
\text { Analgesia } \pm \text { paralysis } \\
30^{\circ} \text { head of bed elevation } \\
\text { Intravenous fluids } \pm \\
\text { inotropes to maintain mean } \\
\text { arterial pressure (MAP) } \\
\geq 80 \text { mmHg } \\
\text { Ventriculostomy } \pm \mathrm{CSF} \\
\text { drainage } \\
\text { Surgical removal of space } \\
\text { occupying lesions } \\
\pm \text { prophylactic } \\
\text { anticonvulsants }\end{array}$ & $\begin{array}{c}\text { STAGE 2 } \\
\text { Mannitol (maintain serum } \\
\text { osmolarity <315 mosmoles) } \\
\text { Hypertonic Saline (avoid in } \\
\text { hyponatraemic patients, } \\
\text { caution in patients with } \\
\text { cardiac or pulmonary } \\
\text { problems) } \\
\text { Inotropes to maintain } \\
\text { cerebral perfusion pressure } \\
\text { (CPP) } \geq 60 \text { mmHg } \\
\text { Monitor blood Magnesium } \\
\text { levels and replace as } \\
\text { required } \\
\text { Barbiturates not } \\
\text { permitted } \\
\pm \text { induced hypothermia }\end{array}$ & $\begin{array}{l}\text { Decompressive } \\
\text { Craniectomy }\end{array}$ \\
\hline
\end{tabular}

Figure 2. Stages of therapeutic management after traumatic brain injury. These'stages' have been developed for use in the Eurotherm3235Trial using evidence synthesis from the Brain Trauma Foundation [73] and the European Brain Injury Consortium [81]. $\mathrm{CSF}$, cerebrospinal fluid; $\mathrm{PaCO}_{2^{\prime}}$ arterial partial pressure of carbon dioxide; $\mathrm{PaO}_{2^{\prime}}$ arterial partial pressure of oxygen. 
hypothermia will continue until ICP is no longer dependent on temperature reduction to remain below $20 \mathrm{~mm} \mathrm{Hg}$. Patients will then be slowly re-warmed at a rate of $0.25^{\circ} \mathrm{C}$ per hour $\left(1^{\circ} \mathrm{C} / 4\right.$ hours $)$.

The experience from previous hypothermia trials underscores the potential difficulties in using therapeutic hypothermia treatment for TBI. For this reason, and to reduce inter-centre variance, only centres experienced with the care of TBI patients and the use of hypothermia (after either cardiac arrest or TBI) will be initiated.

\section{Conclusions}

Many potential neuro-protective pharmacological interventions have been tested and have failed to show benefit in TBI. Common reasons that have been cited include inadequate or low methodological quality preclinical studies and poor (and often underpowered) clinical study design. Hypothermia has extensive preclinical data supporting clinical testing and generally meets the STAIR (Stroke Therapy Academic Industry Roundtable) recommendations [80]. The Eurotherm3235Trial will recruit 1,800 patients in 41 months and will be one of the largest TBI studies to date.

\section{Abbreviations}

$\mathrm{BBB}=$ blood-brain barrier; $\mathrm{Cl}=$ confidence interval; $\mathrm{CNS}=$ central nervous system; $C T=$ computerised tomography; $I C P=$ intracranial pressure; $P K C=$ protein kinase $C ; R C T=$ randomised controlled trial; $R R=$ relative risk; $T B I=$ traumatic brain injury.

\section{Competing interests}

HLS is a trial manager and PJDA is the chief investigator of the

Eurotherm3235Trial (http://www.eurotherm3235trial.eu).

\section{Acknowledgements}

This paper is a summary of the evidence that has supported the design of the Eurotherm3235Trial (http://www.eurotherm3235trial.eu), which is a large multi-national, prospective, randomised controlled trial in patients with raised intracranial pressure after traumatic brain injury.

Published: 15 February 2010

\section{References}

1. European Brain Injury Society homepage [http://www.ebissociety.org/ head-injury.html].

2. Ghajar J: Traumatic brain injury. Lancet 2000, 356:923-929.

3. Polderman $\mathrm{KH}$ : Induced hypothermia and fever control for prevention and treatment of neurological injuries. Lancet 2008, 371:1955-1969.

4. Nolan JP, Deakin CD, Soar J, Böttiger BW, Smith G; European Resuscitation Council: European Resuscitation Council Guidelines for resuscitation: Section 4 Adult Advanced Life Support. Resuscitation 2005, 67 (Suppl 1):s39-s86.

5. American Heart Association: Guidelines for CPR and ECC. Part 7.5 Post-resuscitation support. Circulation 2005, 112 (24 Suppl) IV:84-88.

6. Jacobs S, Hunt R, Tarnow-Mordi W, Inder T, Davis P: Cooling for newborns with hypoxic ischaemic encephalopathy. Cochrane Database Syst Rev 2007, (4):CD003311.

7. Dietrich WD, Bramlett HM: Hypothermia and central nervous system injury. Prog Brain Res 2007, 162:201-217.

8. Clifton GL, Jiang JY, Lyeth BG, Jenkins LW, Hamm RJ, Hayes RL: Marked protection by moderate hypothermia after experimental traumatic brain injury. J Cereb Blood Flow Metab 1991, 11:114-121.

9. Dietrich WD, Alonso O, Busto R, Globus MY, Ginsberg MD: Post-traumatic brain hypothermia reduces histopathological damage following concussive brain injury in the rat. Acta Neuropathol 1994, 87:250-258.
10. Bramlett HM, Green EJ, Dietrich WD, Busto R, Globus MY, Ginsberg MD Posttraumatic brain hypothermia provides protection from sensorimotor and cognitive behavioral deficits. J Neurotrauma 1995, 12:289-298.

11. Koizumi H, Fujisawa H, Ito H, Maekawa T, Di X, Bullock R: Effects of mild hypothermia on cerebral blood flow-independent changes in cortical extracellular levels of amino acids following contusion trauma in the rat. Brain Res 1997, 747:304-312.

12. Dietrich WD, Busto R, Halley M, Valdes I: The importance of brain temperature in alterations of the blood-brain barrier following cerebral ischemia. J Neuropathol Exp Neurol 1990, 49:486-497.

13. Kawai N, Nakamura T, Nagao S: Effects of brain hypothermia on brain edema formation after intracerebral hemorrhage in rats. Acta Neurochir Supp/ 2002, 81:233-235.

14. Park CK, Jun SS, Kim MC, Kang JK: Effects of systemic hypothermia and selective brain cooling on ischemic brain damage and swelling. Acta Neurochir Supp/ 1998, 71:225-228.

15. Mancuso A, Derugin N, Hara K, Sharp FR, Weinstein PR: Mild hypothermia decreases the incidence of transient $A D C$ reduction detected with diffusion MRI and expression of c-fos and hsp70 mRNA during acute focal ischemia in rats. Brain Res 2000, 887:34-45.

16. Nagel S, Su Y, Horstmann S, Heiland S, Gardner H, Koziol J, Martinez-Torres FJ, Wagner S: Minocycline and hypothermia for reperfusion injury after focal cerebral ischemia in the rat: effects on BBB breakdown and MMP expression in the acute and subacute phase. Brain Res 2008, 1188:198-206.

17. Kumar K, Wu X, Evans AT: GFAP-immunoreactivity following hypothermic forebrain ischemia. Metab Brain Dis 1996, 12:21-27.

18. Goss JR, Styren SD, Miller PD, Kochanek PM, Palmer AM, Marion DW, Dekosky ST: Hypothermia attenuates the normal increase in interleukin 1 beta RNA and nerve growth factor following traumatic brain injury in the rat. J Neurotrauma 1995, 12:159-167.

19. Kinoshita K, Chatzipanteli K, Alonso OF, Howard M, Dietrich WD: The effect of brain temperature on hemoglobin extravasation after traumatic brain injury. J Neurosurg 2002, 97:945-953.

20. Vitarbo EA, Chatzipanteli K, Kinoshita K, Truettner JS, Alonso OF, Dietrich WD: Tumor necrosis factor alpha expression and protein levels after fluid percussion injury in rats: the effect of injury severity and brain temperature. Neurosurgery 2004, 55:416-424.

21. Kline AE, Bolinger BD, Kochanek PM, Carlos TM, Yan HQ, Jenkins LW, Marion DW, Dixon CE: Acute systemic administration of interleukin-10 suppresses the beneficial effects of moderate hypothermia following traumatic brain injury in rats. Brain Res 2002, 937:22-31

22. Globus MY, Alonso O, Dietrich WD, Busto R, Ginsberg MD: Glutamate release and free radical production following brain injury: effects of posttraumatic hypothermia. J Neurochem 1995, 65:1704-1711.

23. Sakamoto Kl, Fujisawa H, Koizumi H, Tsuchida E, Ito H, Sadamitsu D, Maekawa $\mathrm{T}$ : Effects of mild hypothermia on nitric oxide synthesis following contusion trauma in the rat. J Neurotrauma 1997, 14:349-353.

24. DeKosky ST, Abrahamson EE, Taffe KM, Dixon CE, Kochanek PM, Ikonomovic MD: Effects of post-injury hypothermia and nerve growth factor infusion on antioxidant enzyme activity in the rat: implications for clinical therapies. J Neurochem 2004, 90:998-1004.

25. Lei B, Tan X, Cai H, Xu Q, Guo Q: Effect of moderate hypothermia on lipid peroxidation in canine brain tissue after cardiac arrest and resuscitation. Stroke 1994, 25:147-152.

26. Van Hemelrijck A, Hachimi-Idrissi S, Sarre S, Ebinger G, Michotte Y: Post-ischaemic mild hypothermia inhibits apoptosis in the penumbral region by reducing neuronal nitric oxide synthase activity and thereby preventing endothelin-1-induced hydroxyl radical formation. Eur J Neurosci 2005, 22:1327-1337.

27. Tohyama Y, Sako K, Yonemasu Y: Hypothermia attenuates hyperglycolysis in the periphery of ischemic core in rat brain. Exp Brain Res 1998, 122:333-338.

28. Lo EH, Steinberg GK, Panahian N, Maidment NT, Newcomb R: Profiles of extracellular amino acid changes in focal cerebral ischaemia: effects of mild hypothermia. Neurol Res 1993, 15:281-287.

29. Mitani A, Kataoka K: Critical levels of extracellular glutamate mediating gerbil hippocampal delayed neuronal death during hypothermia: brain microdialysis study. Neuroscience 1991, 42:661-670.

30. Rokkas CK, Cronin CS, Nitta T, Helfrich LR Jr., Lobner DC, Choi DW, Kouchoukos NT: Profound systemic hypothermia inhibits the release of neurotransmitter amino acids in spinal cord ischemia. J Thorac Cardiovasc Surg 1995, 110:27-35. 
31. Zhu H, Meloni BP, Bojarski C, Knuckey MW, Knuckey NW: Post-ischemic modest hypothermia ( 35 degrees $\mathrm{C}$ ) combined with intravenous magnesium is more effective at reducing $\mathrm{CA} 1$ neuronal death than either treatment used alone following global cerebral ischemia in rats. Exp Neurol 2005, 193:361-368.

32. Friedman LK, Ginsberg MD, Belayev L, Busto R, Alonso OF, Lin B, Globus MY: Intraischemic but not postischemic hypothermia prevents non-selective hippocampal downregulation of AMPA and NMDA receptor gene expression after global ischemia. Brain Res Mol Brain Res 2001, 86:34-47.

33. Lyeth BG, Jiang JY, Robinson SE, Guo H, Jenkins LW: Hypothermia blunts acetylcholine increase in CSF of traumatically brain injured rats. Mol Chem Neuropathol 1993, 18:247-256.

34. Zhang H, Zhou M, Zhang J, Mei Y, Sun S, Tong E: Therapeutic effect of post-ischemic hypothermia duration on cerebral ischemic injury. Neurol Res 2008, 30:332-336.

35. Winfree CJ, Baker CJ, Connolly ES Jr., Fiore AJ, Solomon RA: Mild hypothermia reduces penumbral glutamate levels in the rat permanent focal cerebral ischemia model. Neurosurgery 1996, 38:1216-1222.

36. Rosomoff HL, Holaday DA: Cerebral blood flow and cerebral oxygen consumption during hypothermia. Am J Physiol 1954, 179:85-88.

37. Kuluz JW, Prado R, Chang J, Ginsberg MD, Schleien CL, Busto R: Selective brain cooling increases cortical cerebral blood flow in rats. Am J Physiol 1993, 265:H824-H827.

38. Hu BR, Kamme F, Wieloch T: Alterations of Ca2+/calmodulin-dependent protein kinase II and its messenger RNA in the rat hippocampus following normo- and hypothermic ischemia. Neuroscience 1995, 68:1003-1016.

39. Shimohata T, Zhao H, Steinberg GK: Epsilon PKC may contribute to the protective effect of hypothermia in a rat focal cerebral ischemia model. Stroke 2007, 38:375-380.

40. Akaji K, Suga S, Fujino T, Mayanagi K, Inamasu J, Horiguchi T, Sato S, Kawase T: Effect of intra-ischemic hypothermia on the expression of c-Fos and c-Jun, and DNA binding activity of AP-1 after focal cerebral ischemia in rat brain. Brain Res 2003, 975:149-157.

41. Pabello NG, Tracy SJ, Snyder-Keller A, Keller RW Jr:. Regional expression of constitutive and inducible transcription factors following transient focal ischemia in the neonatal rat: influence of hypothermia. Brain Res 2005, 1038:11-21.

42. Gressens P, Dingley J, Plaisant F, Porter H, Schwendimann L, Verney C, Tooley J, Thoresen M: Analysis of neuronal, glial, endothelial, axonal and apoptotic markers following moderate therapeutic hypothermia and anesthesia in the developing piglet brain. Brain Pathol 2008, 18:10-20.

43. Rationale, Collaborative Approach to Meta Analysis and Review of Animal Data from Experimental Stroke (CAMARADES) [http://www.camarades.info/ index files/Page354.htm].

44. Polderman $\mathrm{KH}$, Ely EW, Badr AE, Girbes AR: Induced hypothermia in traumatic brain injury: considering the conflicting results of metaanalyses and moving forward. Intensive Care Med 2004, 30:1860-1864.

45. Shiozaki T, Hayakata T, Taneda M, Nakajima Y, Hashiguchi N, Fujimi S, Nakamori Y, Tanaka H, Shimazu T, Sugimoto H: A multicenter prospective randomized controlled trial of the efficacy of mild hypothermia for severely head injured patients with low intracranial pressure. Mild hypothermia study group in Japan. J Neurosurg 2001, 94:50-54.

46. Clifton GL, Miller ER, Choi SC, Levin HS, McCauley S, Smith KR Jr., Muizelaar JP, Wagner FC Jr., Marion DW, Luerssen TG, Chesnut RM, Schwartz M: Lack of effect of induction of hypothermia after acute brain injury. N Engl J Med 2001, 344:556-563

47. Shiozaki T, Sugimoto H, Taneda M, Yoshida H, Iwai A, Yoshioka T, Sugimoto T: Effect of mild hypothermia on uncontrollable raised intracranial hypertension after severe head injury. J Neurosurg 1993, 79:363-386.

48. Clifton GL, Allen S, Barrodale P, Plenger P, Berry J, Koch S, Fletcher J, Hayes RL, Choi SC: A phase Il study of moderate hypothermia in severe brain injury. J Neurotrauma 1993, 10:263-271.

49. Marion DW, Penrod LE, Kelsey SF, Obrist WD, Kochanek PM, Palmer AM, Wisniewski SR, DeKosky ST: Treatment of traumatic brain injury with moderate hypothermia. N Engl J Med 1997, 336:540-546.

50. Jiang JY, Yu MK, Zhu C: Effect of long-term mild hypothermia therapy in patients with severe traumatic brain injury: 1 year follow up review of 87 cases. J Neurosurg 2000, 93:546-549.

51. Zhang K, Wang JX: Comparative study on mild hypothermia in patients with severe head injury and the most severe head injury. Inner Mongolian Medical Journal 2000, 32:4-6.
52. Polderman KH, Peerdeman SM, Girbes AR: Hypophosphatemia and hypomagnesemia induced by cooling in patients with severe head injury. J Neurosurg 2001, 94:697-705.

53. Yan $Y$, Tang W: Changes of evoked potentials and evaluation of mild hypothermia for treatment of severe head injury. Chin J Traumatol 2001, 4:8-13.

54. Polderman KH, Tjong Tjin JR, Peerdeman SM, Vandertop WP, Girbes ARJ: Effects of artificially induced hypothermia on intracranial pressure and outcome in patients with severe traumatic brain injury. Intensive Care Med 2002, 28:1563-1567.

55. Gal R, Cundrle I, Smrcka M: Mild hypothermia therapy for patients with severe brain injury. Clin Neurol Neurosurg 2002, 104:318-321.

56. Zhi D, Zhang S, Lin X: Study on therapeutic mechanism and clinical effect of mild hypothermia in patients with severe head injury. Surg Neurol 2003, 59:381-385

57. Liu WG, Qiu WS, Zhang Y, Wang WM, Lu F, Yang XF: Effects of selective brain cooling in patients with severe traumatic brain injury: a preliminary study J Int Med Res 2006, 34:58-64.

58. Jiang JY, Xu W, Li WP, Gao GY, Bao YH, Liang YM, Luo QZ: Effect of long-term mild hypothermia or short-term mild hypothermia on outcome of patients with severe traumatic brain injury. J Cereb Blood Flow Metab 2006, 26:771-776.

59. Qiu W, Zhang Y, Sheng H, Zhang J, Wang W, Liu W, Chen K, Zhou J, Xu Z: Effects of therapeutic mild hypothermia on patients with severe traumatic brain injury after craniotomy. J Crit Care 2007, 22:229-236.

60. Aibiki M, Maekawa S, Yokono S: Moderate hypothermia improves imbalances of thromboxane $\mathrm{A} 2$ and prostaglandin 12 production after traumatic brain injury in humans. Crit Care Med 2000, 28:3902-3906.

61. Marion DW, Obrist WD, Carlier PM, Penrod LE, Darby JM: The use of moderate therapeutic hypothermia for patients with severe head injuries: a preliminary report. J Neurosurg 1993, 79:354-362

62. Qiu WS, Liu WG, Shen H, Wang WM, Hang ZL, Zhang Y, Jiang SJ, Yang XF: Therapeutic effect of mild hypothermia on outcome of patients with severe traumatic brain injury. Chin J Traumatol 2005, 8:27-32.

63. Qiu W, Shen H, Zhang Y, Wang W, Liu W, Jiang Q, Luo M, Manou M: Noninvasive selective brain cooling by head and neck cooling is protective in severe traumatic brain injury. $J$ Clin Neurosci 2006, 13:995-1000

64. Clifton GL, Choi SC, Miller ER, Levin HS, Smith KR Jr., Muizelaar JP, Wagner FC Jr., Marion DW, Luerssen TG: Intercenter variance in clinical trials of head trauma - experience of the National Acute Brain Injury Study: Hypothermia. J Neurosurg 2001, 95:751-755.

65. Fearnside MR, Cook RJ, McDougall P, McNeil RJ: The Westmead Head Injury Project outcome in severe head injury. A comparative analysis of prehospital, clinical and CT variables. Br J Neurosurg 1993, 7:267-279.

66. Chesnut RM, Marshall SB, Piek J, Blunt BA, Klauber MR, Marshall LF: Early and late systemic hypotension as a frequent and fundamental source of cerebral ischemia following severe brain injury in the Traumatic Coma Data Bank. Acta Neurochir Suppl (Wien) 1993, 59:121-125.

67. Ducrocq SC, Meyer PG, Orliaguet GA, Blanot S, Laurent-Vannier A, Renier D, Carli PA: Epidemiology and early predictive factors of mortality and outcome in children with traumatic severe brain injury: experience of a French pediatric trauma center. Pediatr Crit Care Med 2006, 7:461-467.

68. Bernard SA, Gray TW, Buist MD: Treatment of comatose survivors of out-ofhospital cardiac arrest with induced hypothermia. N Engl J Med 2002, 346:557-563

69. Hypothermia after Cardiac Arrest Study Group: Mild therapeutic hypothermia to improve the neurologic outcome after cardiac arrest. N Engl J Med 2002, 346:549-556.

70. Dixon SR: Infarct angioplasty: beyond stents and glycoprotein Ilb/Illa inhibitors. Heart 2005, 91 Suppl 3:iiiz-iii6

71. Polderman KH: Application of therapeutic hypothermia in the intensive care unit; opportunities and pitfalls of a promising treatment modality - Part 2: practical aspects and side effects. Crit Care Med 2004, 30:757-769.

72. Polderman KH, Rijnsburger ER, Peerdeman SM, Girbes AR: Induction of hypothermia in patients with various types of neurologic injury with the use of large volumes of ice-cold intravenous fluid. Crit Care Med 2005, 33:2744-2751

73. Brain Trauma Foundation and American Association of Neurological Surgeons (AANS) and Congress of Neurological Surgeons (CNS) Joint Section on Neurotrauma and Critical Care: Guidelines for the Management of Severe 
Traumatic Brain Injury. 3rd edition. New Rochelle, NY: Mary Ann Liebert, Inc., publishers; 2007.

74. Mclntyre LA, Fergusson DA, Hébert PC, Moher D, Hutchison JS: Prolonged therapeutic hypothermia after traumatic brain injury in adults: a systematic review. JAMA 2003, 289:2992-2999.

75. Harris $\mathrm{OA}$, Colford JM Jr, Good MC, Matz PG: The role of hypothermia in the management of severe brain injury: a meta-analysis. Arch Neurol 2002, 59:1077-1083

76. Henderson WR, Dhingra VK, Chittock DR, Fenwick JC, Ronco JJ: Hypothermia in the management of traumatic brain injury: a systematic review and meta-analysis. Intensive Care Med 2003, 29:1637-1644.

77. Alderson P, Gadkary C, Signorini DF: Therapeutic hypothermia for head injury. Cochrane Database Syst Rev 2004, (4):CD001048.

78. Peterson K, Carson S, Cairney N: Hypothermia treatment for traumatic brain injury: a systematic review and meta-analysis. J Neurotrauma 2008, 25:62-71
79. Sydenham E, Roberts I, Alderson P: Hypothermia for traumatic head injury. Cochrane Database Syst Rev 2009, (1):CD001048.

80. Sydenham E, Roberts I, Alderson P: Hypothermia for traumatic head injury Cochrane Database Syst Rev 2009, (2):CD001048,

81. Maas Al, Dearden M, Teasdale GM, Braakman R, Cohadon F, lannotti F, Karimi A, Lapierre F, Murray G, Ohman J, Persson L, Servadei F, Stocchetti N, Unterberg A: EBIC-guidelines for management of severe head injury in adults. European Brain Injury Consortium. Acta Neurochir (Wien) 1997, 139:286-294

doi:10.1186/cc8220

Cite this article as: Sinclair HL, Andrews PJD: Bench-to-bedside review: Hypothermia in traumatic brain injury. Critical Care 2010, 14:204. 